\title{
Antiparasitic Potential of Chromatographic Fractions of Nephrolepis biserrata and Liquid Chromatography-Quadrupole Time-of-Flight-Mass Spectrometry Analysis
}

\author{
Muhammad Dawood Shah ${ }^{1}$, Kazuki Tani ${ }^{2}$, Yoong Soon Yong ${ }^{3}{ }^{\mathbb{D}}$, Fui Fui Ching ${ }^{1}$, \\ Sitti Raehanah Muhamad Shaleh ${ }^{1}$, Charles S. Vairappan ${ }^{2}\left(\mathbb{D}\right.$ and Balu Alagar Venmathi Maran ${ }^{1, *(\mathbb{C})}$ \\ 1 Borneo Marine Research Institute, Universiti Malaysia Sabah, Kota Kinabalu, \\ Jalan UMS 88450, Sabah, Malaysia; dawoodshah@ums.edu.my (M.D.S.); cfuifui@ums.edu.my (F.F.C.); \\ sittirae@ums.edu.my (S.R.M.S.) \\ 2 Laboratory of Natural Products Chemistry, Institute for Tropical Biology and Conservation, \\ Universiti Malaysia Sabah, Kota Kinabalu, Jalan UMS 88450, Sabah, Malaysia; \\ tani_kindaisuiken@yahoo.co.jp (K.T.); csv@ums.edu.my (C.S.V.) \\ 3 Laboratory Centre, Xiamen University Malaysia, Jalan Sunsuria, Bandar Sunsuria, \\ Sepang 43900, Selangor, Malaysia; yoongsoon.yong@xmu.edu.my \\ * Correspondence: bavmaran@ums.edu.my; Tel.: +60-16-209-6905
}

Citation: Shah, M.D.; Tani, K.; Yong, Y.S.; Ching, F.F.; Shaleh, S.R.M.; Vairappan, C.S.; Venmathi Maran, B.A. Antiparasitic Potential of Chromatographic Fractions of Nephrolepis biserrata and Liquid Chromatography-Quadrupole Time-of-Flight-Mass Spectrometry Analysis. Molecules 2021, 26, 499 https://doi.org/10.3390/molecules 26020499

Academic Editor: Simone Carradori Received: 30 November 2020 Accepted: 31 December 2020 Published: 19 January 2021

Publisher's Note: MDPI stays neutral with regard to jurisdictional clai$\mathrm{ms}$ in published maps and institutional affiliations.

Copyright: (C) 2021 by the authors. Licensee MDPI, Basel, Switzerland. This article is an open access article distributed under the terms and conditions of the Creative Commons Attribution (CC BY) license (https:// creativecommons.org/licenses/by/ $4.0 /)$.

\begin{abstract}
Marine aquaculture development is recently impeded by parasitic leech Zeylanicobdella arugamensis (Hirudinea, Piscicolidae) in Sabah, Malaysia. The parasitic leech infests a variety of cultured fishes in aquaculture facilities. In this study, we evaluated the antiparasitic activity of the chromatographic fractions of the medicinal plant Nephrolepis biserrata methanol extract against $Z$. arugamensis and highlighted the potential metabolites responsible for the antiparasitic properties through liquid chromatography (LC)-quadrupole time-of-flight (QTOF)-mass spectrometry (MS) analysis. Out of seven fractions obtained through flash column chromatography techniques, three fractions demonstrated antiparasitic properties. Significant parasitic mortality was indicated by fraction 3 at a concentration of $2.50 \mathrm{mg} / \mathrm{mL}$, all the leeches were killed in a time limit of $1.92 \pm 0.59 \mathrm{~min}$. followed by fraction $4(14 \mathrm{mg} / \mathrm{mL})$ in $34.57 \pm 3.39$ and fraction $5(15.3 \mathrm{mg} / \mathrm{mL})$ in $36.82 \pm 4.53 \mathrm{~min}$. LC-QTOF-MS analysis indicated the presence of secondary metabolites including phytosphingosine (6), pyrethrosin (1), haplophytine (9), ivalin (2), warburganal (3), isodomedin (4) and pheophorbide a (16), representing sphingoid, alkaloid, terpenoid, phenolic and flavonoid groups. Thus, our study indicated that the chromatographic fractions of $N$. biserrata demonstrated significant antiparasitic activity against the marine parasitic leeches due to the presence of potent antiparasitic bioactive compounds.
\end{abstract}

Keywords: natural products; aquaculture; grouper; Zeylanicobdella; antiparasitic; secondary metabolites; leeches; LC-QTOF-MS

\section{Introduction}

The high demand for the fish product and decrement of ocean fisheries due to overfishing and deterioration of coastal environments which have triggered the rapid development of aquaculture facilities in Malaysia and other parts of the world, lead to the expansion of brackish-water and marine aquaculture [1,2]. Accordingly, the reputation of parasites as disease-causing agents in aquaculture has become evident $[3,4]$. Fish parasites are not only responsible for commercial losses in aquaculture and fisheries industries but also cause socio-economic implications both in developing and developed countries [5,6]. Different types of parasites including leeches (Annelida), monogeneans (Platyhelminthes), caligids (Crustacea), etc., are affecting various species of fishes [7-10].

Among the marine parasitic leeches, Zeylanicobdella arugamensis de Silva, 1963 (Hirudinea, Piscicolidae) is commonly found in Malaysia, Indonesia, Brunei, Philippines, Japan and other 
South-East Asian countries $[3,4,7,11-13]$. The leech is characterized by having an asymmetrical flattened cylindrical body with anterior and posterior suckers and has been considered to be the most harmful ectoparasite affecting a large variety of species of fish [3,7]. The mortality of the host fish typically occurs within three days following infection due to secondary pathogenic bacterial invasion [3].

Due to the lack of registered biocontrol agents, farmers use toxic chemicals including formalin for the removal of parasites in aquaculture industries [14]. The chemicals are extremely harmful to fish, humans and the environment [15]. Thus, it is very important to develop a natural control agent to minimize the application of toxic chemicals. A plant can be used as a biocontrol agent due to the presence of different antiparasitic phytochemicals. Nephrolepis biserrata (Nephrolepidaceae) is a tropical fern known as "Paku larat" in Malay $[16,17]$. The plant is a good source of antioxidant compounds with hepatoprotective potential [18]. The antimicrobial activity of the plant has been reported [19], however, the antiparasitic potential of the plant has not yet been reported. Thus, in the current study, we analyzed the antiparasitic potential of the chromatographic fractions of N. biserrata methanol extract against the marine parasitic leech and profiled the phytochemical composition via LC-QTOF-MS analysis.

\section{Results}

\subsection{Antiparasitic Activity of the Chromatographic Fractions of N. biserrata Methanol Extract}

The sample plant was extracted with methanol and further chromatographic fractions of the methanol extract were obtained by flash column chromatography techniques. Various concentrations of the chromatographic fractions of $N$. biserrata methanol extract were prepared and the leeches were exposed (Figure 1). The death time and percentage of the seawater-, formalin- and fractions-treated groups are indicated in Table 1 (Table S1). No mortality was noticed in the negative control group (Figure 1a) while 100 per cent mortality was recorded in the positive control group treated with $0.25 \% v / v$ of formalin solution (Figure 1b). In the groups treated with fractions 1, 2, 6 and 7 no mortalities of the leeches were observed while complete mortality was noticed in the groups treated with fractions 3,4 and 5 . In this regard, the group treated with fraction 3 killed all the leeches in a time limit of $1.92 \pm 0.59 \mathrm{~min}$ at a concentration of $2.50 \mathrm{mg} / \mathrm{mL}$, while fractions 4 and 5 killed all the leeches in $34.57 \pm 3.39(14.0 \mathrm{mg} / \mathrm{mL})$ and $36.82 \pm 4.53 \mathrm{~min}(15.3 \mathrm{mg} / \mathrm{mL})$ (Figure 1c,d). The leeches were considered as dead only when they were not able to move their body even after touching with forceps (Figure $1 \mathrm{~b}-\mathrm{d}$ ).

Table 1. Death time and percentage of the fractions of N. biserrata against the marine leeches.

\begin{tabular}{|c|c|c|c|}
\hline No & Group & $\begin{array}{l}\text { Death Time (min) } \\
\text { Mean } \pm \text { S.D. }\end{array}$ & Death Percentage \\
\hline 1 & Negative Control & $000 \pm 0.00$ & 0 \\
\hline 2 & Positive Control (Formalin $0.025 \%$ ) & $3.90 \pm 0.84 \#$ & 100 \\
\hline 3 & Fraction 1 (4.80 mg/mL) & $000 \pm 0.00 *$ & 0 \\
\hline 4 & Fraction $2(20 \mathrm{mg} / \mathrm{mL})$ & $000 \pm 0.00 *$ & 0 \\
\hline 5 & Fraction $3(2.50 \mathrm{mg} / \mathrm{mL})$ & $1.92 \pm 0.59^{\# * \wedge \$}$ & 100 \\
\hline 6 & Fraction $4(14 \mathrm{mg} / \mathrm{mL})$ & $34.57 \pm 3.39 \# *^{\wedge} \$ \&$ & 100 \\
\hline 7 & Fraction $5(15.30 \mathrm{mg} / \mathrm{mL})$ & $36.82 \pm 4.53^{\# *^{\wedge} \$ \&}$ & 100 \\
\hline 8 & Fraction $6(17.20 \mathrm{mg} / \mathrm{mL})$ & $000 \pm 0.00 * \& \alpha \AA$ & 00 \\
\hline 9 & Fraction $7(20 \mathrm{mg} / \mathrm{mL})$ & $000 \pm 0.00 * \& \beta \AA$ & 00 \\
\hline
\end{tabular}

Values are mean \pm SD of six leeches per group. Fraction 1 [hexane: ethyl acetate (H:E) 9:1)]; Fraction 2 (H:E, 8:2); Fraction 3 (H:E, 7:3); Fraction 4 (H:E, 6:4); Fraction 5 (H:E, 5:5); Fraction 6 (H:E, 4:6), Fraction 7 (E, 100\%).

\# Significance at $p<0.05$ compared with the negative control group. * Significance at $p<0.05$ compared with the formalin $[0.25 \%(v / v)]$. ^ Significance at $p<0.05$ compared with fraction $1(4.80 \mathrm{mg} / \mathrm{mL}) .{ }^{\$}$ Significance at $p<0.05$ compared with fraction $2(20 \mathrm{mg} / \mathrm{mL})$. \& Significance at $p<0.05$ compared with fraction $3(2.50 \mathrm{mg} / \mathrm{mL})$ $\alpha$ Significance at $p<0.05$ compared with fraction $4(14 \mathrm{mg} / \mathrm{mL}) .{ }^{\circledR}$ Significance at $p<0.05$ compared with fraction $5(15.30 \mathrm{mg} / \mathrm{mL}) .{ }^{\beta}$ Significance at $p<0.05$ compared with fraction $6(17.20 \mathrm{mg} / \mathrm{mL})$. 


\subsection{Behavioural Changes Induced by the Chromatographic Fractions of N. biserrata Methanol Extract}

The leeches treated with seawater indicated no behavioral changes. They were attached firmly to the bottom of the plate using their caudal or posterior sucker, demonstrating a normal swimming pattern (Figure 1). The exposure of parasitic leeches to fractions 3 , 4 and 5 groups resulted in behavioral changes. The parasitic leeches treated with fraction 3 showed aggressive movements for the first $0.5-1 \mathrm{~min}$. Then, the leeches were not able to attach using their posterior suckers to the bottom of the plate. After $1 \mathrm{~min}$., the leeches became too weak, stopped movement and were dead eventually. Similarly, the leeches exposed to fractions 4 and 5 indicated aggressive swimming for the first 5-10 $\mathrm{min}$. and then their activity decreased slowly. After 25-30 min., the leeches became too weak and showed no movement, even after touched using forceps and finally considered them as died. No behavioral changes were noticed in the groups treated with fractions 1, 2, 6 and 7 of the chromatographic fractions of $N$. biserrata methanol extract, they were swimming normally and attached firmly to the plate surface.
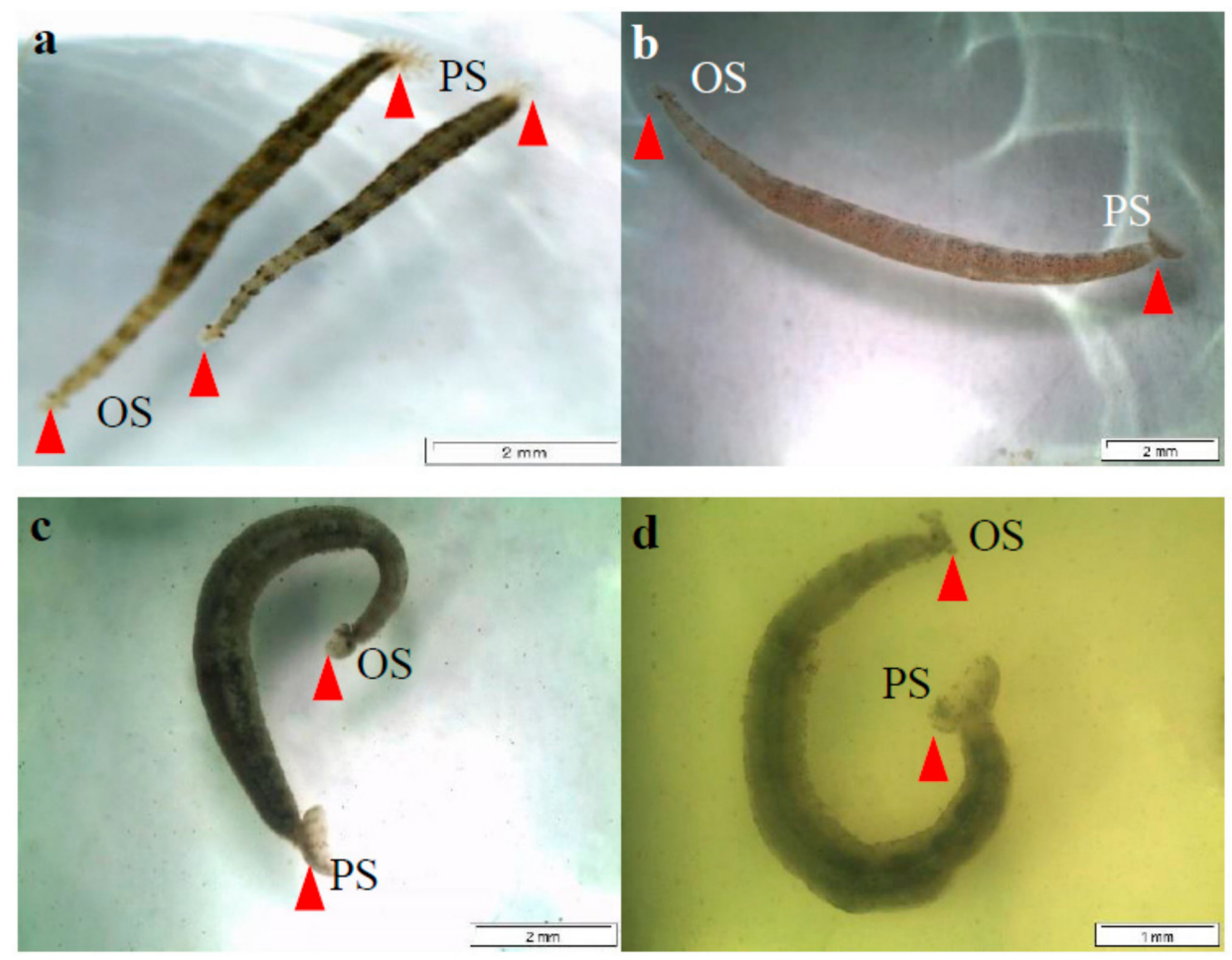

Figure 1. Zeylanicobdella arugamensis, arrow indicates both $\mathrm{OS}=$ oral or anterior sucker and PS = posterior or caudal sucker. (a) = treated with seawater only, arrow indicated to show the posterior sucker attached firmly to the bottom of the plate, $(\mathbf{b})=$ treated with chemical formalin, here posterior sucker detached, $(\mathbf{c}, \mathbf{d})=$ treated with chromatographic fractions of the methanol extract of $N$. biserrata, showing the detachment of posterior sucker.

\subsection{Phytochemical Compounds Detected in the Chromatographic Fractions of N. biserrata Methanol Extract}

All seven frictions of $N$. biserrata extract were subjected to LC-QTOF-MS analysis. Among the 566 molecular features extracted via LC-QTOF-MS analysis, a total of 34 secondary metabolites and one chlorophyll breakdown compound were matched successfully. Some of these secondary metabolites were pyrethrosin (1), ivalin (2), warburganal (3), isodomedin (4), 3'-deoxydryopteric acid (5), phytosphingosine (6), 8-oxo9,11-octadecadiynoic acid (7), 10,16-heptadecadien-8-ynoic acid (8), haplophytine (9), $5,2^{\prime}, 4^{\prime}$-trihydroxy-3,7,8,5'-tetramethoxy flavone (10), 3,5,6,7-tetramethoxy flavone (11), 3,4,5-trimethoxycinnamic acid (12), 3,4-methylenedioxy-2' ', $4^{\prime}$-dimethoxychalcone (13), 9tetradecenyl acetate (14), 3,7,17,23-tetrahydroxycholan-24-oic acid (15), and pheophorbide 
a (16). In overall, we successfully matched six terpenoids, four phenolics, one sphingoid, four fatty acids, two alkaloids, six flavonoids, six aromatics, one aliphatic acetate and four steroids. The retention time, molecular formula and class of the secondary metabolites matched in the fractions of N. biserrata via LC-QTOF-MS analysis are shown in Table 2 along with their chromatograms (Figure 2a-c). While the chemical structures of fraction 3 , 4 and 5 metabolites are indicated in Figure $3 a-c$.

Table 2. Secondary metabolite profiles in fractions of N. biserrata analyzed via LC-QTOF-MS.

\begin{tabular}{|c|c|c|c|c|c|c|}
\hline Fractions & $\begin{array}{l}\text { Retention } \\
\text { Time (RT) }\end{array}$ & $\begin{array}{c}\text { Mass to } \\
\text { Charge Ratio, } \\
\mathrm{m} / \mathrm{z}\end{array}$ & Formula & $\begin{array}{c}\text { Mass } \\
\text { Error, ppm }\end{array}$ & Matched Metabolites & Class \\
\hline 1 & 13.144 & 203.1043 & $\mathrm{C}_{11} \mathrm{H}_{16} \mathrm{O}_{2}$ & -1.39 & 3-tert-Butyl-5-methylcatechol & Phenolic \\
\hline \multirow[t]{6}{*}{2} & 12.848 & 231.1377 & $\mathrm{C}_{15} \mathrm{H}_{18} \mathrm{O}_{2}$ & 0.30 & Isodehydrocostus lactone & Terpenoid \\
\hline & 13.112 & 203.1045 & $\mathrm{C}_{11} \mathrm{H}_{16} \mathrm{O}_{2}$ & -1.39 & 3-tert-Butyl-5-methylcatechol & Phenolic \\
\hline & 13.443 & 311.1847 & $\mathrm{C}_{17} \mathrm{H}_{26} \mathrm{O}_{5}$ & -0.46 & $\begin{array}{l}\text { methyl 8-[2-(2-formyl-vinyl)-3-hydroxy-5-oxo- } \\
\text { cyclopentyl]-octanoate }\end{array}$ & Fatty acid methyl ester \\
\hline & 16.533 & 280.1905 & $\mathrm{C}_{16} \mathrm{H}_{25} \mathrm{~N} \mathrm{O}_{3}$ & -0.37 & Serratine & Alkaloid \\
\hline & 19.234 & 425.2905 & $\mathrm{C}_{24} \mathrm{H}_{40} \mathrm{O}_{6}$ & -1.51 & $(3 \alpha, 5 \beta, 6 \alpha, 7 \alpha)-2,3,6,7-$ Tetrahydroxycholan-24-oic acid & Steroid \\
\hline & 24.443 & 431.3522 & $\mathrm{C}_{28} \mathrm{H}_{46} \mathrm{O}_{3}$ & -0.03 & 1,25-Dihydroxy-ethylidene-19-norvitamin $\mathrm{D}_{3}$ & Steroid \\
\hline \multirow[t]{6}{*}{3} & 12.220 & 318.3001 & $\mathrm{C}_{18} \mathrm{H}_{39} \mathrm{NO}_{3}$ & 0.93 & Phytosphingosine (6) & Sphingoid \\
\hline & 14.096 & 307.1541 & $\mathrm{C}_{17} \mathrm{H}_{22} \mathrm{O}_{5}$ & -0.38 & Pyrethrosin (1) & Terpenoid \\
\hline & 15.081 & 291.1954 & $\mathrm{C}_{18} \mathrm{H}_{26} \mathrm{O}_{3}$ & -0.04 & 8-oxo-9,11-octadecadiynoic acid (7) & Oxo Fatty acid \\
\hline & 15.343 & 263.2002 & $\mathrm{C}_{17} \mathrm{H}_{26} \mathrm{O}_{2}$ & 1.19 & 10,16-Heptadecadien-8-ynoic acid (8) & Fatty Acid \\
\hline & 19.835 & 593.2766 & $\mathrm{C}_{35} \mathrm{H}_{36} \mathrm{~N}_{4} \mathrm{O}_{5}$ & -0.86 & Pheophorbide a (16) & $\begin{array}{l}\text { Chlorophyll breakdown } \\
\text { product }\end{array}$ \\
\hline & 20.777 & 653.2969 & $\mathrm{C}_{37} \mathrm{H}_{40} \mathrm{~N}_{4} \mathrm{O}_{7}$ & 0.46 & Haplophytine (9) & Alkaloid \\
\hline \multirow[t]{5}{*}{4} & 10.663 & 333.0965 & $\mathrm{C}_{17} \mathrm{H}_{16} \mathrm{O}_{7}$ & 1.05 & $3^{\prime}$-Deoxydryopteric acid (5) & Phenolic \\
\hline & 11.325 & 391.1018 & $\mathrm{C}_{19} \mathrm{H}_{18} \mathrm{O}_{9}$ & 1.34 & $5,2^{\prime}, 4^{\prime}$-Trihydroxy-3,7,8, $5^{\prime}$-tetramethoxyflavone (10) & Flavonoid \\
\hline & 11.404 & 239.0911 & $\mathrm{C}_{12} \mathrm{H}_{14} \mathrm{O}_{5}$ & 0.11 & 3,4,5-Trimethoxycinnamic acid (12) & Aromatic \\
\hline & 14.927 & 277.2138 & $\mathrm{C}_{16} \mathrm{H}_{30} \mathrm{O}_{2}$ & 0.12 & 9-Tetradecenyl acetate (14) & Aliphatic acetate \\
\hline & 15.120 & 249.1483 & $\mathrm{C}_{15} \mathrm{H}_{20} \mathrm{O}_{3}$ & -0.32 & Ivalin (2) & Terpenoid \\
\hline \multirow[t]{5}{*}{5} & 12.796 & 251.1636 & $\mathrm{C}_{15} \mathrm{H}_{22} \mathrm{O}_{3}$ & 1.86 & Warburganal (3) & Terpenoid \\
\hline & 13.223 & 313.1070 & $\mathrm{C}_{18} \mathrm{H}_{16} \mathrm{O}_{5}$ & 0.75 & 3,4-Methylenedioxy-2', $4^{\prime}$-dimethoxychalcone (13) & Aromatic \\
\hline & 13.245 & 343.1176 & $\mathrm{C}_{19} \mathrm{H}_{18} \mathrm{O}_{6}$ & 0.27 & 3,5,6,7-Tetramethoxyflavone (11) & Flavonoid \\
\hline & 13.964 & 415.2085 & $\mathrm{C}_{22} \mathrm{H}_{32} \mathrm{O}_{6}$ & 1.05 & Isodomedin (4) & Terpenoid \\
\hline & 15.651 & 447.2719 & $\mathrm{C}_{24} \mathrm{H}_{40} \mathrm{O}_{6}$ & -1.27 & 3,7,17,23-Tetrahydroxycholan-24-oic acid (15) & Steroid \\
\hline \multirow[t]{6}{*}{6} & 8.965 & 465.1018 & $\mathrm{C}_{21} \mathrm{H}_{20} \mathrm{O}_{12}$ & 1.83 & Herbacetin 3-glucoside & Flavonoid \\
\hline & 10.052 & 611.1391 & $\mathrm{C}_{30} \mathrm{H}_{26} \mathrm{O}_{14}$ & 1.04 & Gallocatechin-(4alpha- > 8)-epigallocatechin & Flavonoid \\
\hline & 12.306 & 290.269 & $\mathrm{C}_{16} \mathrm{H}_{32} \mathrm{O}_{3}$ & 0.26 & 14-hydroxy-hexadecanoic acid & Fatty acid \\
\hline & 13.230 & 343.117 & $\mathrm{C}_{19} \mathrm{H}_{18} \mathrm{O}_{6}$ & 1.78 & 3,5,6,7-Tetramethoxyflavone & Flavonoid \\
\hline & 13.983 & 415.2086 & $\mathrm{C}_{22} \mathrm{H}_{32} \mathrm{O}_{6}$ & 1.55 & Isodomedin & Terpenoid \\
\hline & 21.127 & 391.2845 & $\mathrm{C}_{24} \mathrm{H}_{38} \mathrm{O}_{4}$ & -0.89 & 3,7-Dihydroxychol-22-en-24-oic acid & Steroid \\
\hline \multirow[t]{11}{*}{7} & 2.053 & 328.1393 & $\mathrm{C}_{15} \mathrm{H}_{18} \mathrm{O}_{7}$ & -0.86 & Picrotin & Terpenoid \\
\hline & 7.065 & 163.0386 & $\mathrm{C}_{9} \mathrm{H}_{6} \mathrm{O}_{3}$ & 1.15 & 3-Hydroxycoumarin & Aromatic \\
\hline & 7.309 & 355.1016 & $\mathrm{C}_{16} \mathrm{H}_{18} \mathrm{O}_{9}$ & 1.62 & Chlorogenic Acid & Phenolic \\
\hline & 8.945 & 465.1020 & $\mathrm{C}_{21} \mathrm{H}_{20} \mathrm{O}_{12}$ & 1.89 & Herbacetin 3-glucoside & Flavonoid \\
\hline & 9.008 & 291.0975 & $\mathrm{C}_{14} \mathrm{H}_{14} \mathrm{~N}_{2} \mathrm{O}_{5}$ & -0.40 & N2-Malonyl-D-tryptophan & Aromatic \\
\hline & 9.333 & 303.0500 & $\mathrm{C}_{15} \mathrm{H}_{10} \mathrm{O}_{7}$ & -1.53 & Melanoxetin & Flavonoid \\
\hline & 9.333 & 449.1077 & $\mathrm{C}_{21} \mathrm{H}_{20} \mathrm{O}_{11}$ & 0.25 & Kaempferol 5-glucoside & Flavonoid \\
\hline & 10.034 & 404.1341 & $\mathrm{C}_{20} \mathrm{H}_{18} \mathrm{O}_{8}$ & -0.71 & Glucosyloxyanthraquinone & Aromatic \\
\hline & 12.296 & 290.2687 & $\mathrm{C}_{16} \mathrm{H}_{32} \mathrm{O}_{3}$ & 1.23 & 14-hydroxy-hexadecanoic acid & Fatty acid \\
\hline & 13.994 & 432.2381 & $\mathrm{C}_{24} \mathrm{H}_{30} \mathrm{O}_{6}$ & -0.39 & Magnoshinin & Aromatic \\
\hline & 17.923 & 506.2541 & $\mathrm{C}_{30} \mathrm{H}_{32} \mathrm{O}_{6}$ & -1.45 & Rubraflavone D & Phenolic \\
\hline
\end{tabular}




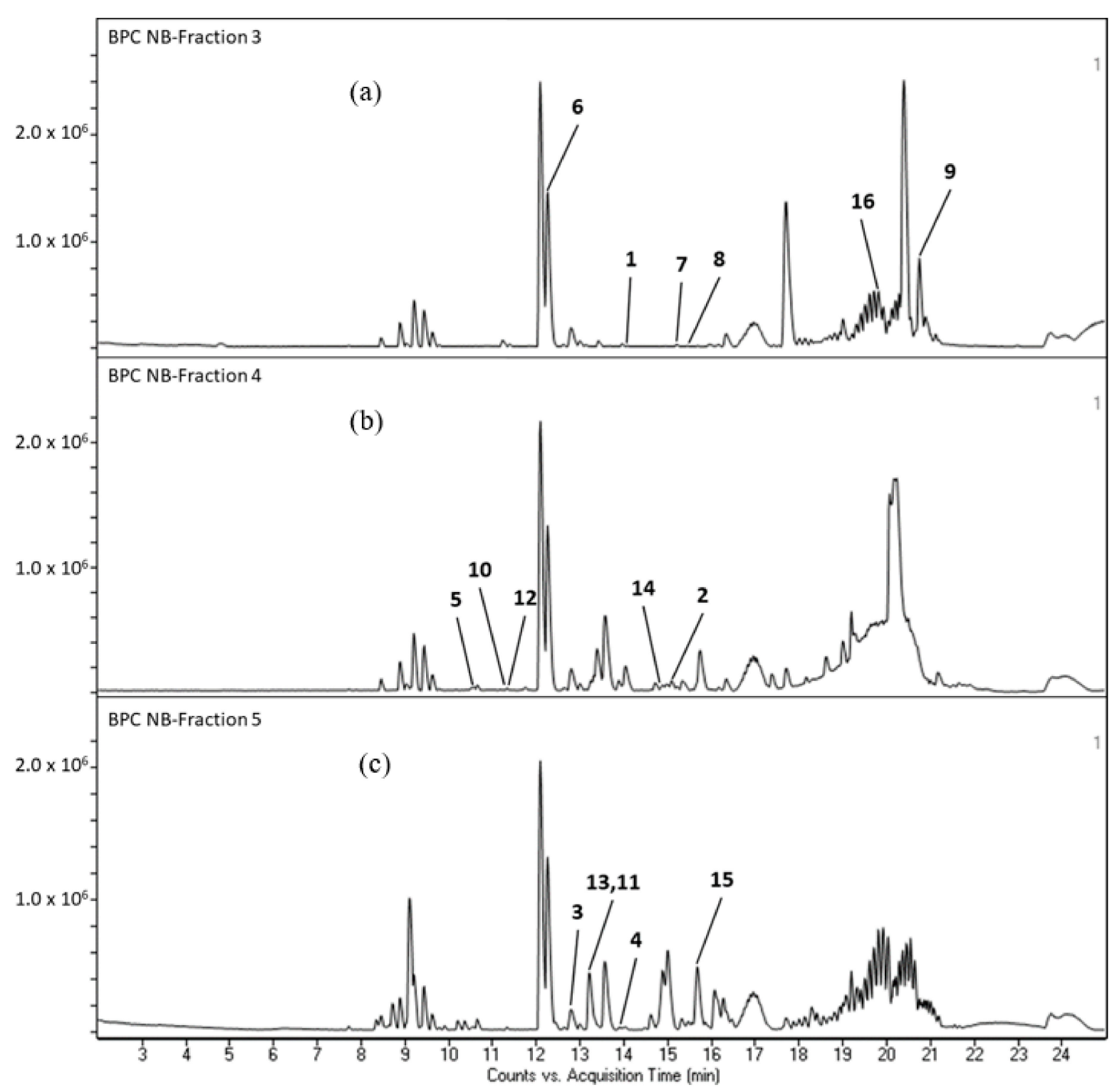

Figure 2. (a) Chromatogram of fraction 3 of N. biserrata. Pyrethrosin (1), phytosphingosine (6), 8-oxo-9,11-octadecadiynoic acid (7), 10,16-heptadecadien-8-ynoic acid (8), haplophytine (9), pheophorbide a (16). (b) Chromatogram of fraction 4 . Ivalin (2), 3'-deoxydryopteric acid (5), 5,2' ,4'-trihydroxy-3,7,8,5'-tetramethoxyflavone (10), 3,4,5-trimethoxycinnamic acid (12), 9-tetradecenyl acetate (14). (c) Chromatogram of fraction 5. Warburganal (3), isodomedin (4), 3,5,6,7-tetramethoxyflavone (11), 3,4-methylenedioxy-2', 4'-dimethoxychalcone (13), 3,7,17,23-tetrahydroxycholan-24-oic acid (15). 
(a)<smiles>C=C1C(=O)OC2CC3(C)OC3CC/C(C)=C/C(OC(C)=O)C12</smiles>

(1)<smiles>CCCCCCCCCCCCCCC(O)C(O)C(N)CO</smiles><smiles>CCCCCCC#CC#CC(=O)CCCCCCC(=O)O</smiles>

(9)

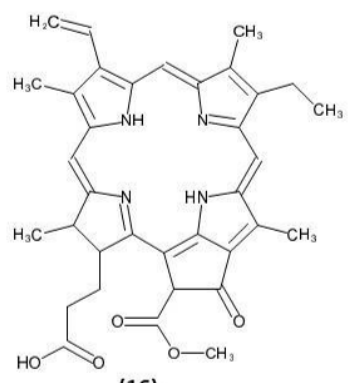

(16)

(b)<smiles>C=CCCCC/C=C/C#CCCCCCCC(=O)O</smiles>

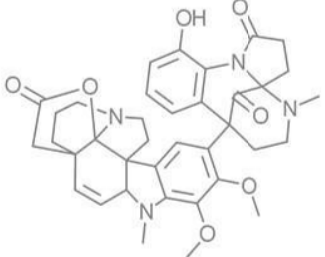<smiles>C=C1C(=O)OC2CC3(C)CC(O)CC(=C)C3CC12</smiles>

(2)<smiles>O=C(O)CC1c2c(O)cc(O)cc2OC(c2ccc(O)cc2)C1O</smiles>

(5)<smiles>CCCC/C=C/CCCCCCCCCOC(C)=O</smiles>

(14)<smiles>COc1c(O)cc(-c2oc3c(OC)c(O)c(OC)c(O)c3c(=O)c2OC)cc1OC1OC(CO)C(O)C(O)C1O</smiles><smiles>COc1cc(/C=C/C(=O)O)cc(OO)c1OC</smiles>

(c)<smiles>CC1(C)CCC[C@]2(C)C1CC=C(C=O)C2(C)C=O</smiles>

(3)

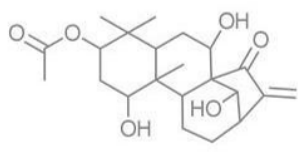

(4)<smiles>CC(CC(O)C(=O)O)[C@]1(O)CCC2C3C(O)CC4CC(O)CCC4(C)C3CC[C@]21C</smiles>

(15)<smiles>COc1cc2oc(-c3ccccc3)c(OC)c(=O)c2c(OC)c1OC</smiles>

(11)<smiles>COc1ccc(C(=O)/C=C/c2ccc3c(c2)OCO3)c(OC)c1</smiles>

(13)

(10)

Figure 3. (a) Chemical structures of the secondary metabolites detected in the chromatographic fraction 3 of $N$. biserrata. Pyrethrosin (1), phytosphingosine (6), 8-oxo-9,11-octadecadiynoic acid (7), 10,16-heptadecadien-8-ynoic acid (8), haplophytine (9), pheophorbide a (16). (b) Chemical structures of the secondary metabolites detected in the chromatographic fraction 4. Ivalin (2), 3'-deoxydryopteric acid (5), 5,2' ,4'-trihydroxy-3,7,8,5'-tetramethoxyflavone (10), 3,4,5-trimethoxycinnamic acid (12), 9-tetradecenyl acetate (14). (c) Chemical structures of the secondary metabolites detected in the chromatographic fraction 5. Warburganal (3), isodomedin (4), 3,5,6,7-tetramethoxyflavone (11), 3,4-methylenedioxy-2' $4^{\prime}$-dimethoxychalcone (13), 3,7,17,23-tetrahydroxycholan-24-oic acid (15).

\section{Discussion}

To minimize the consumption of toxic chemicals against parasites in aquaculture industries, development and application of natural agent is crucial [7,20]. For this purpose, 
the phytotherapy of fish disinfestation against parasites and diseases is a good alternative due to the presence of various phytochemical compounds [21]. The chromatographic fractions 3, 4 and 5 of the methanol extract of $N$. biserrata demonstrated significant antiparasitic potential against the marine parasitic leech.

Compared to our study some other plants have also been reported with antiparasitic properties such as the chromatographic fractions of the methanol extract of Dillenia suffruticosa (Dilleneacea) (known as "Simpoh ayer" in Malay) [22]. A fraction of the methanol extract of D. suffruticosa resulted in the total mortality of Z. arugamensis at a concentration of $20 \mathrm{mg} / \mathrm{mL}$ in a time limit of $31 \mathrm{~min}$ [22]. The active component of Piper nigrum (Piperaceae) (black pepper) has been applied against branchiuran ectoparasite Argulus spp. infesting goldfish Carassius auratus at a concentration ranging from 1 to $9 \mathrm{mg} / \mathrm{L}$. Total mortality $(100 \%)$ of the parasite has been reported at $9.0 \mathrm{mg} / \mathrm{L}$ in $3 \mathrm{~h} \mathrm{[23].} \mathrm{The} \mathrm{methanol} \mathrm{extract}$ of Radix Bupleuri chinensis (roots of Bupleuri chinensis, known as "Chai $\mathrm{Hu}^{\prime}$ in Chinese) (Umbelliferae) tested for their in vivo antiparasitic properties against monogenean Dactylogyrus intermedius in goldfish. The parasites were exposed to the extract at a concentration of $10 \mathrm{mg} / \mathrm{L}$ and more than $90 \%$ of elimination was recorded in $48 \mathrm{~h}$ [24]. The methanol extract of Magnolia officinalis (Magnoliaceae) (known as "Houpo" in Chinese) and Sophora alopecuroides (Leguminosae) (known as "Ku dou zi" in Chinese) plants have been reported as having antiparasitic properties [25-27]. The methanol extract of M. officinalis and S. alopecuroides at a concentration of $40 \mathrm{mg} / \mathrm{L}$ and $120 \mathrm{mg} / \mathrm{L}$, respectively, were applied against the ciliate parasite Ichthyophthirius multifiliis infesting goldfish for $1 \mathrm{~h}$. The extract of the plants reduced the prevalence of parasites by $24.7 \%$ and $44.7 \%$, respectively [27]. From the abovementioned different studies, it is evidently proved that the medicinal plants have the potent antiparasitic properties [22-27]. Compared to these plants, the chromatographic fractions of the methanol extract of our sample have shown much better activity such as fraction 3 killing all leeches in $1.92 \mathrm{~min}$. In addition to this, the mortality time shown by fraction 3 was almost half compared to formalin $(3.90 \mathrm{~min}$ ) (Table 1). It is interesting to reveal that the fraction 3 of $N$. biserrata is more effective than formalin in addition to the safe and healthy nature of the plant $[7,15,28]$.

The LCMS analysis indicated the presence of various metabolites with antimicrobial, anti-inflammatory and antiparasitic potential [29-35]. Though there is a lack of information regarding the antiparasitic potential of these metabolites against marine parasites, their effectiveness against other parasites were widely reported [29-35]. Some of the important metabolites are phytosphingosine (6), a naturally occurring lipid which acts as antimicrobial (gram-positive bacteria, yeast and moulds) and anti-inflammatory [29]. It also induces mitochondria-mediated apoptosis (cell death) by the fragmentation of chromatin DNA in human T-cell lymphoma Jurkat cells [30]. Pheophorbide a (16), a chlorophyll breakdown product, has been reported to have antiparasitic properties against Leishmania amazonensis, responsible for the disease leishmaniasis [31]. Additionally, the bioactive compound has been reported as having antiviral, antiinflammatory, antioxidant and immunomodulatory properties [32-35]. Haplophytine (9), an alkaloid, has been reported to have insecticidal properties [36]. These 3 metabolites are detected in fraction 3 of N. biserrata which indicated very strong antiparasitic properties by killing all the leeches in less than $2 \mathrm{~min}$ (Table 1). It is suggested that the effectiveness of fraction 3 could be due to the presence of these metabolites. Ivalin (2), a terpenoid, has been reported to have antiparasitic activity against the Trypanosoma brucei rhodesiense and T. cruzi [37]. It also induces apoptosis in human hepatocellular carcinoma SMMC-7721 Cells [38]. Another terpenoid, warburganal (3), along with polygodial bioactive compounds, has been reported with antihelminthic (Caenorhabditis elegans) activity [39]. Warburganal has also been reported with molluscicidal properties [40]. Isodomedin (4), a diterpene, has been reported with antifeedant properties against the larvae of African armyworm, Spodoptera exenzpta [41]. These compounds have been detected in fractions 4 and 5 of $N$. biserrata (Table 2). Though different types of bioactive compounds were also detected in fractions $1,2,6$, and 7 , as well, no significant inhibition or behavioral changes of Z. arugamensis were observed. These phenomena might 
be due to the resistance of $Z$. arugamensis toward these compounds or the presence of low contents of these bioactive compounds.

\section{Materials and Methods}

\subsection{Chemicals}

A mixture of hexane and ethyl acetate was used for column preparation and fractionation. Silica gel $\left(\mathrm{SiO}_{2}\right)$ and normal phase thin layer chromatography plate were obtained from Merck, Germany. Developed TLCs were visualized using 5 per cent molybdophosphoric acid in ethanol was purchased from Nacalai, Japan. Formalin (37 per cent aqueous formaldehyde solution) was bought from Sigma, Leica, Microsystem (Darmstadt, Germany), Methanol (HPLC grade) was purchased from Merck (Darmstadt, Germany). LCMSgrade acetonitrile was obtained from J. T. Baker (Philipsburg, NJ, USA). Polyvinylidene fluoride (PVDF) syringe filters $(0.22 \mu \mathrm{m}$ pore size and $13 \mathrm{~mm}$ diameter) were bought from Merck (Darmstadt, Germany). Deionized water was acquired via a Milli-Q system (Merck, Darmstadt, Germany) at a resistivity of $>18.2 \mathrm{M} \Omega \cdot \mathrm{cm}$. Reference mass solution containing $5.0 \mathrm{mM}$ of purine and $2.5 \mathrm{mM}$ of Hexakis $[1 \mathrm{H}, 1 \mathrm{H}, 3 \mathrm{H}$-tetrafluoropropoxy] phosphazine, was procured from Agilent Technologies (Santa Clara, CA, USA). LCMS-grade formic acid (HCOOC) was acquired from Fisher Scientific (Fair Lawn, NJ, USA).

\subsection{Plant Collection}

Aerial parts of the plants were obtained from Universiti Malaysia Sabah $\left(5.7346^{\circ} \mathrm{N}\right.$, $115.9319^{\circ} \mathrm{E}$ ) in Sept 2019 on a sunny day with a minimum temperature of 24 and a maximum temperature of $35^{\circ} \mathrm{C}$. The plant was identified, a voucher specimen was deposited at the Institute for Tropical Biology and Conservation, Universiti Malaysia Sabah, Kota Kinabalu, Malaysia (Figure 4).

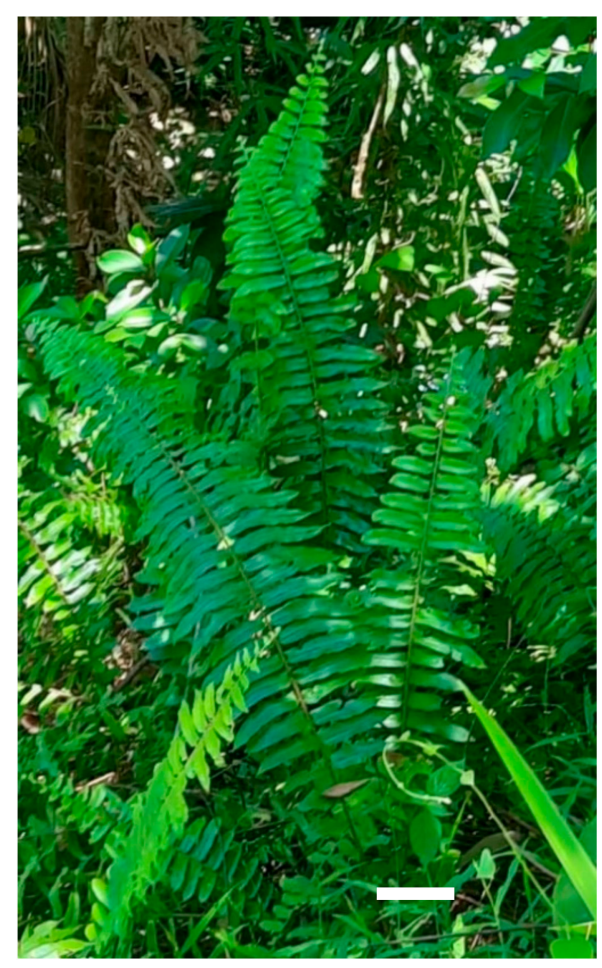

Figure 4. Nephrolepis biserrata fern collected from Universiti Malaysia Sabah, scale bar: $5 \mathrm{~cm}$.

\subsection{Extraction and Fractionation}

The leaves of the plants were cleaned with distilled water and dried by oven at $37^{\circ} \mathrm{C}$. The dried sample was grounded in a heavy-duty grinder and placed in an airtight jar. Methanol (300 mL, HPLC grade) was used for the extraction of the powder (60 g) via the 
Soxhlet method (50-60 ${ }^{\circ} \mathrm{C}$ for $72 \mathrm{~h}$ ). The dry extract was recovered using a vacuum rotary evaporator, before lyophilization using a freeze drier [42].

Using a $20 \times 100 \mathrm{~mm}$ glass column with a $250 \mathrm{~mL}$ reservoir, flash column chromatography was carried out. The column was prepared with $\mathrm{SiO}_{2}$ gel infused in hexane. Around $500 \mathrm{mg}$ of the methanol extract of $\mathrm{N}$. biserrata was dissolved in $2 \mathrm{~mL}$ of hexane and spiked onto the column once the column settled. The spiked silica gel ( $\mathrm{SiO} 2)$ was eluted with a solvent-gradient Hexane-Ethyl Acetate eluant system; F1-Hex:EtOAc (9:1), F2-Hex:EtOAc (8:2), F3-Hex:EtOAc (7:3), F4-Hex:EtOAc (6:4), F5-Hex:EtOAc (5:5), F6-Hex:EtOAc (4:6), F7EtOAc $(100 \%)$ was used to fractionate. A total of seven fractions were collected, each was about $250 \mathrm{~mL}$ in volume, fractions were evaporated under vacuo using a vacuum rotary evaporator, before removing the solvent residues using a $\mathrm{N}_{2}$ flushed desiccation. Then, their profiles were determined using thin-layer chromatography to notice their separation. Besides, fractions were subjected to LC-QTOF-MS analysis to determine the inherently present secondary metabolites.

\subsection{Antiparasitic Bioassay}

The parasitic leeches were isolated from the infested hybrid groupers (Epinephelus fuscoguttatus $\times$ E. lanceolatus), Universiti Malaysia Sabah and identified based on its morphological features [7]. The mature leeches were divided into 9 groups (5 leeches per group) and as follows.

Group 1 = negative control, treated with seawater.

Group 2 = positive control, treated with $0.25 \%$ formalin solution.

Group 3 = treated with $N$. biserrata fraction $1(4.80 \mathrm{mg} / \mathrm{mL})$.

Group $4=$ treated with $N$. biserrata fraction $2(20 \mathrm{mg} / \mathrm{mL})$.

Group $5=$ treated with $N$. biserrata fraction $3(2.50 \mathrm{mg} / \mathrm{mL})$.

Group $6=$ treated with $N$. biserrata fraction $4(14 \mathrm{mg} / \mathrm{mL})$.

Group $7=$ treated with $N$. biserrata fraction $5(15.30 \mathrm{mg} / \mathrm{mL})$.

Group $8=$ treated with $N$. biserrata fraction $6(17.20 \mathrm{mg} / \mathrm{mL})$.

Group $9=$ treated with $N$. biserrata fraction $7(20 \mathrm{mg} / \mathrm{mL})$.

Different concentration of fractions was applied according to the fractionation yield ratio of the methanol extract of $N$. biserrata to identify the effective fractions against $Z$. arugamensis. The time limit was recorded until all the leeches were killed after the exposure to various concentrations of chromatographic fractions of methanol extract of $N$. biserrata [43].

\subsection{Behavioural Observation}

The behavior of $Z$. arugamensis was also monitored visually during the exposure to different concentrations of the chromatographic fractions of $N$. biserrata and compared with normal and positive control groups [43].

\subsection{LC-QTOF MS Acquisition}

The fractions were analyzed as described previously [22], where Agilent 1290 Infinity LC system coupled with an Agilent 6520 QTOF-MS system was employed. Briefly, a $2.0 \mu \mathrm{L}$ sample was injected and separated with an Agilent Zorbax Eclipse XDB-C18 column (narrow bore, $2.1 \mathrm{~mm} \times 150 \mathrm{~mm} \times 3.5 \mu \mathrm{m}$; Agilent Technologies, Santa Clara, CA, USA) at a flow rate of $0.5 \mathrm{~mL} / \mathrm{min}$. Column chamber was maintained at $25^{\circ} \mathrm{C}$ during analysis. Solvents A $\left(\mathrm{H}_{2} \mathrm{O}-0.1 \% \mathrm{HCOOH}\right)$ and $\mathrm{B}$ (acetonitrile- $\left.0.1 \% \mathrm{HCOOH}\right)$ were used as the mobile phases, and the gradient was programmed at $5 \%$ solvent $B$ from 0 to $5 \mathrm{~min}$, then from $5 \%$ to $100 \%$ solvent $\mathrm{B}$ in $15 \mathrm{~min}$ and kept for $5 \mathrm{~min}$, before column re-conditioning as initial for next injection.

Mass spectrometry (MS) data acquisition range was set from $\mathrm{m} / \mathrm{z}$ of 100 to 1500 . Heated electrospray ionization (ESI) was deployed at $4 \mathrm{kV}$ in positive mode. The ion source was set as follows: $300{ }^{\circ} \mathrm{C}$ of gas temperature, $10 \mathrm{~L} / \mathrm{min}$ of drying gas flow, and 45 psig of nebulizer flow. Tuning Mix (Agilent Technologies, Santa Clara, CA, USA) was used for system calibration before analysis. During analysis, internal mass calibration standards 
betaine and hexakis $(1 \mathrm{H}, 1 \mathrm{H}, 3 \mathrm{H}$-tetrafluoropropoxy) phosphazine were introduced. In positive mode, the internal mass calibration standards were $\mathrm{m} / \mathrm{z}$ of 121.0508 and 922.0097, respectively.

Automated tandem mass spectrometry (auto-MS/MS) was performed for metabolites matching, on which two precursor ions were selected from each MS scan and subjected for collision-induced dissociation with $20 \mathrm{eV}$ of collision energy. Data acquisition range for auto-MS/MS was set between an $\mathrm{m} / \mathrm{z}$ of 50 and 1500, and purified nitrogen gas was used as the collision gas. Acquired data were processed using Agilent MassHunter Qualitative Workflows software (version B.08.00) and the extracted metabolite MS were identified via METLIN metabolites and lipids databases [44] with 2 ppm maximum mass tolerance.

\subsection{Statistical Analysis}

Data analysis was done via IBM SPSS Statistics 25 Window package (IBM, Armonk, NY, US). One-way variance analysis (ANOVA) followed by Tukey's multiple comparison test was applied to determine the significant differences between groups All findings were presented as mean \pm standard deviation (S.D.). $p$-Values of less than 0.05 were considered to be significant.

\section{Conclusions}

In this study, fractions 3, 4 and 5 of $N$. biserrata demonstrated antiparasitic properties among the seven fractions obtained through flash column chromatography techniques. Significant parasitic mortality was indicated by fraction 3 at a concentration of $2.5 \mathrm{mg} / \mathrm{mL}$, all the parasitic leeches were killed in a time limit of only $1.92 \pm 0.59 \mathrm{~min}$. followed by fraction $4(14 \mathrm{mg} / \mathrm{mL}) 34.57 \pm 3.39$ and fraction $5(15.3 \mathrm{mg} / \mathrm{mL})$ in an average time of $36.82 \pm 4.53 \mathrm{~min}$. In a very low concentration $(2.5 \mathrm{mg} / \mathrm{mL})$, the methanol extract of $N$. biserrata could effectively kill the parasites infesting the cultured grouper. LC-QTOF-MS analysis indicated the presence of secondary metabolites including phytosphingosine (6), pyrethrosin (1), haplophytine (9), ivalin (2), warburganal (3), isodomedin (4) and pheophorbide a (16) representing sphingoid, alkaloid, terpenoid, phenolic and flavonoid groups. Thus, our study indicated that $N$. biserrata fractions contained some effective and potent bioactive compounds with antiparasitic potential.

Supplementary Materials: Table S1: Data of death time and percentage of the fractions of N. biserrata against the marine leeches in replicates.

Author Contributions: M.D.S.: investigation, methodology, data curation, formal analysis, writing original draft, review and editing; K.T.: data curation, formal analysis; Y.S.Y.: data curation, formal analysis, review and editing; F.F.C.: supervision, review and editing; S.R.M.S.: supervision, review and editing; C.S.V.: data curation, formal analysis, review and editing; B.A.V.M.: conceptualization, investigation; methodology, supervision, validation, visualization, writing original draft, review and editing, funding acquisition and project administration. All authors have read and agreed to the published version of the manuscript.

Funding: This study was funded by the Universiti Malaysia Sabah (SDN0073-2019), (PRF No. 00112019) and Fundamental Research Grant Scheme, the Ministry of Education Malaysia (grant/award no. FRG0486-2018).

Data Availability Statement: The data presented in this study are available in manuscript and supplementary material.

Conflicts of Interest: The authors declare no conflict of interest.

\section{References}

1. Rosenberg, A.A. The price of lice. Nature 2008, 451, 23-24. [CrossRef] [PubMed]

2. Othman, M.F.; Hashim, M.; Eim, Y.M.; Azmai, M.N.A.; Iksan, N.; Chong, H.G.; Merican, Z. Transforming the aquaculture industry in Malaysia. World Aquac. 2017, 48, 16-23.

3. Ravi, R.; Yahaya, Z.S. Zeylanicobdella arugamensis, the marine leech from cultured crimson snapper (Lutjanus erythropterus), Jerejak Island, Penang, Malaysia. Asian Pac. J. Trop. Biomed. 2017, 7, 473-477. [CrossRef] 
4. Murwantoko, M.; Negoro, S.L.C.; Isnansetyo, A.; Zafran, Z. Short communication: Identification of marine leech and assessment of its prevalence and intensity on cultured hybrid groupers (Epinephelus sp.). Biodiversitas 2018, 19, 1798-1804. [CrossRef]

5. Shinn, A.A.P.; Pratoomyot, J.; Bron, J.E.; Paladini, G.G.; Brooker, E.; Brooker, A.J. Economic impacts of aquatic parasites on global finfish production. Glob. Aquac. Advocate 2015, 2015, 82-84.

6. Barber, I.; Hoare, D.; Krause, J. Effects of parasites on fish behaviour: A review and evolutionary perspective. Rev. Fish Biol. Fish 2000, 10, 131-165. [CrossRef]

7. Shah, M.D.; Venmathi Maran, B.A.; Haron, F.K.; Ching, F.F.; Shaleh, S.R.M.; Ransangan, J.; Yong, Y.-S.; Shapawi, R.; Ohtsuka, S. Antiparasitic potential of Nephrolepis biserrata methanol extract against the parasitic leech Zeylanicobdella arugamensis (Hirudinea) and LC-QTOF analysis. Sci. Rep. 2020, 10, 22091. [CrossRef]

8. Khoa, T.N.D.; Mazelan, S.; Muda, S.; Shaharom-Harrison, F. Use of neem oil (Azadirachta indica) to control caligid copepod infestation on Asian seabass (Lates calcarifer). Aquac. Res. 2019, 50, 1885-1892. [CrossRef]

9. De Oliveira Hashimoto, G.S.; Neto, F.M.; Ruiz, M.L.; Acchile, M.; Chagas, E.C.; Chaves, F.C.M.; Martins, M.L. Essential oils of Lippia sidoides and Mentha piperita against monogenean parasites and their influence on the hematology of Nile tilapia. Aquaculture 2016, 450, 182-186. [CrossRef]

10. Venmathi Maran, B.A.; Seng, L.T.; Ohtsuka, S.; Nagasawa, K. Records of Caligus (Crustacea: Copepoda: Caligidae) from marine fish cultured in floating cages in Malaysia with a redescription of the male of Caligus longipedis Bassett-Smith, 1898. Zool. Stud. 2009, 48, 797-807.

11. Azmey, S.; Taruna, M.; Taha, H.; Arai, T. Prevalence and infestation intensity of a piscicolid leech, Zeylanicobdella arugamensis on cultured hybrid grouper in Brunei Darussalam. Vet. Parasitol. Reg. Stud. Rep. 2020, 20, 100398. [CrossRef] [PubMed]

12. Cruz-Lacierda, E.R.; Toledo, J.D.; Tan-Fermin, J.D.; Burreson, E.M. Marine leech (Zeylanicobdella arugamensis) infestation in cultured orange-spotted grouper, Epinephelus coioides. Aquaculture 2000, 185, 191-196. [CrossRef]

13. Nagasawa, K.; Uyeno, D. Zeylanicobdella arugamensis (Hirudinea, Piscicolidae), a leech infesting brackish-water fishes, new to Japan. Biogeography 2009, 11, 125-130.

14. Francis-Floyd, R. Use of formalin to control fish parasites. Coll. Vet. Med. Institue Food Agric. Sci. 1996, 77, 7-9.

15. Fischer, M.H. The toxic effects of formaldehyde and formalin. J. Exp. Med. 1905, 6, 487-518. [CrossRef]

16. MyBIS Nephrolepis biserrata | Nephrolepidaceae I Malaysia Biodiversity Information System. Available online: https://www. mybis.gov.my/sp/63552 (accessed on 24 September 2020).

17. Kulip, J.; Fan, L.N.; Manshoor, N.; Julius, A.; Said, I.M.; Gisil, J.; Joseph, J.A.; Tukin, W.F. Medicinal plants in Maliau Basin, Sabah, Malaysia. J. Trop. Biol. Conserv. 2010, 6, 21-33.

18. Shah, M.D.; Gnanaraj, C.; Haque, A.E.; Iqbal, M. Antioxidative and chemopreventive effects of Nephrolepis biserrata against carbon tetrachloride (CCl4)-induced oxidative stress and hepatic dysfunction in rats. Pharm. Biol. 2015, 53, 31-39. [CrossRef]

19. Dantu, P.; Rani, D.; Khare, P. In vitro antibacterial and antifungal properties of aqueous and non-aqueous frond extracts of Psilotum nudum, Nephrolepis biserrata and Nephrolepis cordifolia. Indian J. Pharm. Sci. 2010, 72, 818. [CrossRef]

20. Shariff, M.; Nagaraj, G.; Chua, F.H.; Wang, Y.G. The use of chemicals in aquaculture in Malaysia and Singapore. In Use of Chemicals in Aquaculture in Asia: Proceedings of the Meeting on the Use of Chemicals in Aquaculture in Asia 20-22 May 1996, Tigbauan, Iloilo, Philippines; Aquaculture Department, Southeast Asian Fisheries Development Center: Iloilo, Philippines, $2000 ;$ pp. 127-140.

21. Valladão, G.M.R.; Gallani, S.U.; Pilarski, F. Phytotherapy as an alternative for treating fish disease. J. Vet. Pharmacol. Ther. 2015, 38, 417-428. [CrossRef]

22. Shah, M.D.; Tani, K.; Venmathi Maran, B.A.; Yong, Y.S.; Fui Fui, C.; Shaleh, S.R.M.; Vairappan, C.S. High-resolution chemical profiling and antiparasitic potential of the tropical shrub Dillenia suffruticosa. Fish. Sci. 2020. [CrossRef]

23. Kumar, A.; Raman, R.P.; Kumar, K.; Pandey, P.K.; Kumar, V.; Mohanty, S.; Kumar, S. Antiparasitic efficacy of piperine against Argulus spp. on Carassius auratus (Linn. 1758): In vitro and in vivo study. Parasitol. Res. 2012, 111, 2071-2076. [CrossRef] [PubMed]

24. Wu, Z.F.; Zhu, B.; Wang, Y.; Lu, C.; Wang, G.X. In vivo evaluation of anthelmintic potential of medicinal plant extracts against Dactylogyrus intermedius (Monogenea) in goldfish (Carassius auratus). Parasitol. Res. 2011, 108, 1557-1563. [CrossRef] [PubMed]

25. Luo, H.; Wu, H.; Yu, X.; Zhang, X.; Lu, Y.; Fan, J.; Tang, L.; Wang, Z. A review of the phytochemistry and pharmacological activities of Magnoliae officinalis cortex. J. Ethnopharmacol. 2019, 236, 412-442. [CrossRef]

26. Wang, R.; Deng, X.; Gao, Q.; Wu, X.; Han, L.; Gao, X.; Zhao, S.; Chen, W.; Zhou, R.; Li, Z.; et al. Sophora alopecuroides L.: An ethnopharmacological, phytochemical, and pharmacological review. J. Ethnopharmacol. 2020, 248, 112172. [CrossRef] [PubMed]

27. Yi, Y.L.; Lu, C.; Hu, X.G.; Ling, F.; Wang, G.X. Antiprotozoal activity of medicinal plants against Ichthyophthirius multifiliis in goldfish (Carassius auratus). Parasitol. Res. 2012, 111, 1771-1778. [CrossRef]

28. Pitten, F.A.; Kramer, A.; Herrmann, K.; Bremer, J.; Koch, S. Formaldehyde neurotoxicity in animal experiments. Pathol. Res. Pract. 2000, 196, 193-198. [CrossRef]

29. Pavicic, T.; Wollenweber, U.; Farwick, M.; Korting, H.C. Anti-microbial and -inflammatory activity and efficacy of phytosphingosine: An in vitro and in vivo study addressing acne vulgaris. Int. J. Cosmet. Sci. 2007, 29, 181-190. [CrossRef]

30. Nagahara, Y.; Shinomiya, T.; Kuroda, S.; Kaneko, N.; Nishio, R.; Ikekita, M. Phytosphingosine induced mitochondria-involved apoptosis. Cancer Sci. 2005, 96, 83-92. [CrossRef] 
31. Miranda, N.; Volpato, H.; da Silva Rodrigues, J.H.; Caetano, W.; Ueda-Nakamura, T.; de Oliveira Silva, S.; Nakamura, C.V. The photodynamic action of pheophorbide a induces cell death through oxidative stress in Leishmania amazonensis. J. Photochem. Photobiol. B Biol. 2017, 174, 342-354. [CrossRef]

32. Ohta, S.; Ono, F.; Shiomi, Y.; Nakao, T.; Aozasa, O.; Nagate, T.; Kitamura, K.; Yamaguchi, S.; Nishi, M.; Miyata, H. Anti-herpes simplex virus substances produced by the marine green alga, Dunaliella primolecta. J. Appl. Phycol. 1998, 10, 349-356. [CrossRef]

33. Ratnoglik, S.L.; Aoki, C.; Sudarmono, P.; Komoto, M.; Deng, L.; Shoji, I.; Fuchino, H.; Kawahara, N.; Hotta, H. Antiviral activity of extracts from Morinda citrifolia leaves and chlorophyll catabolites, pheophorbide a and pyropheophorbide a, against hepatitis C virus. Microbiol. Immunol. 2014, 58, 188-194. [CrossRef] [PubMed]

34. Lauritano, C.; Helland, K.; Riccio, G.; Andersen, J.H.; Ianora, A.; Hansen, E.H. Lysophosphatidylcholines and chlorophyll-derived molecules from the diatom Cylindrotheca closterium with anti-inflammatory activity. Mar. Drugs 2020, 18. [CrossRef] [PubMed]

35. Saide, A.; Lauritano, C.; Ianora, A. Pheophorbide a: State of the Art. Mar. Drugs 2020, 18, 257. [CrossRef]

36. Saxton, J.E. Chapter 18 Alkaloids of Haplophyton Cimicidum. In Alkaloids: Chemistry and Physiology; Academic Press: Cambridge, MA, USA, 1965; Volume 8, pp. 673-678.

37. Schmidt, T.J.; Brun, R.; Willuhn, G.; Khalid, S.A. Anti-trypanosomal activity of Helenalin and some structurally related sesquiterpene lactones. Planta Med. 2002, 68, 750-751. [CrossRef]

38. Liu, F.; Lin, S.; Zhang, C.; Ma, J.; Han, Z.; Jia, F.; Xie, W.; Li, X. The novel nature microtubule inhibitor ivalin induces G2/M arrest and apoptosis in human hepatocellular carcinoma SMMC-7721 cells in vitro. Medicina 2019, 55, 470. [CrossRef] [PubMed]

39. Liu, M.; Kipanga, P.; Mai, A.H.; Dhondt, I.; Braeckman, B.P.; De Borggraeve, W.; Luyten, W. Bioassay-guided isolation of three antihelminthic compounds from Warburgia ugandensis Sprague subspecies ugandensis, and the mechanism of action of polygodial. Int. J. Parasitol. 2018, 48, 833-844. [CrossRef] [PubMed]

40. Nakanishi, K.; Kubo, I. Studies on Warburganal, Muzigadial and related compounds. Isr. J. Chem. 1977, 16, 28-31. [CrossRef]

41. Kubo, I.; Miura, I.; Nakanishi, K.; Kamikawa, T.; Isobe, T.; Kubota, T. Structure of Isodomedin, a novel ent-kaurenoid diterpene. J. Chem. Soc. Chem. Commun. 1977, 555. [CrossRef]

42. Srivastava, R.; Srivastava, P. Hepatotoxicity and the role of some herbal hepatoprotective plants in present scenario. Int. J. Dig. Dis. 2018, 4, 1-4. [CrossRef]

43. Shah, M.D.; Venmathi Maran, B.A.; Iqbal, M.; Ching, F.F.; Lal, M.T.M.; Othman, R.O.; Shapawi, R. Antiparasitic activity of the medicinal plant Dillenia suffruticosa against the marine leech Zeylanicobdella arugamensis (Hirudinea) and its phytochemical composition. Aquac. Res. 2020, 51, 215-221. [CrossRef]

44. Guijas, C.; Montenegro-Burke, J.R.; Domingo-Almenara, X.; Palermo, A.; Warth, B.; Hermann, G.; Koellensperger, G.; Huan, T.; Uritboonthai, W.; Aisporna, A.E.; et al. METLIN: A technology platform for identifying knowns and unknowns. Anal. Chem. 2018, 90, 3156-3164. [CrossRef] [PubMed] 